\title{
Milk protein-derived peptide inhibitors of angiotensin-I-converting enzyme
}

\author{
Richard J. FitzGerald ${ }^{1 *}$ and H. Meisel ${ }^{2}$ \\ ${ }^{1}$ Department of Life Sciences, University of Limerick, Limerick, Ireland \\ ${ }^{2}$ Bundesanstalt für Milchforschung, Institut für Chemie und Physik, Kiel, Germany
}

\begin{abstract}
Numerous casein and whey protein-derived angiotensin-I-converting enzyme (ACE) inhibitory peptides/hydrolysates have been identified. Clinical trials in hypertensive animals and humans show that these peptides/hydrolysates can bring about a significant reduction in hypertension. These peptides/hydrolysates may be classified as functional food ingredients and nutraceuticals due to their ability to provide health benefits i.e. as functional food ingredients in reducing the risk of developing a disease and as nutraceuticals in the prevention/treatment of disease.
\end{abstract}

Peptides/hydrolysates: Hypertension: Functional foods/nutraceuticals

\section{Introduction}

Angiotensin-I-converting enzyme (ACE) is a key enzyme in the regulation of peripheral blood pressure. ACE, a dipeptide-liberating carboxypeptidase (peptidyldipeptide hydrolase, EC 3.4.15.1), classically associated with the renin-angiotensin system, converts angiotensin I into angiotensin II, a highly potent vasoconstrictor molecule (Skeegs et al. 1956). Several endogenous peptides such as enkephalins, bradykinin and substance $\mathrm{P}$ are inhibitors and competitive substrates for ACE (Maruyama et al. 1987a; Steve et al. 1988). In the kinin kallikrein system, for example, ACE activates bradykinin, a vasodilatory molecule (Erdos, 1975). This enzyme, therefore, plays a key physiological role in the regulation of local levels of several endogenous bioactive peptides. Exogenous ACE inhibitors having an antihypertensive effect in vivo were first discovered in snake venom (Ondetti et al. 1977). Several food protein sources including fish, gelatin and maize protein contain ACE-inhibitory peptides (for reviews see Ariyoshi, 1993; Meisel, 1993). Milk proteins are also precursors for a range of peptides which inhibit ACE (Meisel, 1993; Takano, 1998; FitzGerald \& Meisel, 1999). Casein-derived inhibitors of ACE are known as casokinins (Meisel, 1993), whereas whey-derived inhibitors are known as lactokinins (FitzGerald \& Meisel, 1999).

\section{General structural features of milk protein-derived ACE inhibitory peptides}

Casokinin sequences have been found in $\alpha_{\mathrm{s} 1^{-}}, \beta-$, and $\kappa$ casein, and lactokinins in $\alpha$-lactalbumin, $\beta$-lactoglobulin and bovine serum albumin (Tables 1 and 2). Two strategies have generally been used in the identification and characterisation of such peptides, i.e. isolation of inhibitory peptides from in vitro enzymatic digests of milk proteins and chemical synthesis of peptides or peptide analogues having similar structures to those known to inhibit ACE.

Structure-activity correlations between different peptide inhibitors of ACE indicate that binding to ACE is strongly influenced by the $\mathrm{C}$-terminal tripeptide sequence of the substrate. Although the precise substrate specificity is not fully understood, ACE appears to prefer substrates or competitive inhibitors containing hydrophobic (aromatic or branched side-chains) amino acid residues at each of the three C-terminal positions. ACE inhibition studies with dipeptides of varying structure, show that C-terminal tryptophan, tyrosine, phenylalanine or proline residues were most effective in enhancing substrate binding (Cheung et al. 1980). All casokinins, i.e. casein-derived ACE inhibitory peptides have proline, lysine or arginine as the C-terminal residue (Table 1). However, the presence of positively charged C-terminal lysine or arginine residues in casokinins, bradykinin and some synthetic inhibitors (Cheung et al. 1980) does not fit with the ACE active site model proposed by Ondetti \& Cushman (1982). Nevertheless, structure-activity data suggest that the positive charge on the guanidino or $\varepsilon$-amino group of $\mathrm{C}$ terminal arginine and lysine side-chains, respectively, contribute substantially to inhibitory potency. For example, replacement of arginine at the C-terminus of bradykinin results in an essentially inactive analogue (Meisel, 1993). It is postulated that the mechanism of ACE inhibition involves inhibitor interaction with an anionic binding site which is distinct from the catalytic site. Given the above, it is expected that peptide conformation, i.e. the structure adopted in a specific environment, should contribute to ACE inhibitor potency. A detailed knowledge of the

\footnotetext{
* Corresponding author: R. J. FitzGerald
} 
Table 1. Bovine casein-derived angiotensin-I-converting enzyme (ACE) inhibitory peptides*

\begin{tabular}{|c|c|c|c|c|c|c|}
\hline \multicolumn{2}{|c|}{ Peptide fragment/analogue } & $\begin{array}{l}\text { Primary structure } \\
\text { (one letter code) }\end{array}$ & $\begin{array}{c}\mathrm{IC}_{50}^{\dagger} \\
(\mu \mathrm{mol} / \mathrm{l})\end{array}$ & $\begin{array}{l}\text { Enzymatic } \\
\text { hydrolysis }\end{array}$ & $\begin{array}{l}\text { Peptide } \\
\text { synthesis }\end{array}$ & Reference \\
\hline \multirow[t]{14}{*}{$\alpha_{\mathrm{S} 1}$-casein } & $f(23-34)$ & FFVAPFPEVFGK & 77 & + & - & Maruyama \& Suzuki, 1982; Maruyama et al. 1985 \\
\hline & $f(23-37)$ & FFVAP & 6 & + & - & Maruyama et al. 1985 \\
\hline & $f(24-27)$ & FVAP & 10 & - & + & Maruyama et al. 1987a \\
\hline & $f(25-27)$ & VAP & 2 & - & + & Maruyama et al. $1987 a$ \\
\hline & $f(27-30)$ & PFPE & $>1000$ & - & + & Maruyama et al. 1987a \\
\hline & $f(28-34)$ & FPEVFGK & 140 & + & - & Maruyama et al. $1987 a$ \\
\hline & $f(32-34)$ & FGK & 160 & - & + & Maruyama et al. $1987 a$ \\
\hline & $f(104-109)$ & YKVPQL & 22 & + & - & Maeno et al. 1996 \\
\hline & $f(142-147)$ & LAYFYP & 65 & + & - & Pihlanto-Leppälä et al. 1998 \\
\hline & $f(143-148)$ & AYFYPE & $106^{\ddagger}$ & + & - & Yamamoto et al. 1994 \\
\hline & $f(157-164)$ & DAYPSGAW & 98 & + & - & Pihlanto-Leppälä et al. 1998 \\
\hline & $f(194-199)$ & TTMPLW & 16 & + & - & Maruyama et al. 1987b \\
\hline & $f(197-199)$ & PLW & 36 & - & + & Maruyama et al. 1987b \\
\hline & $f(198-199)$ & LW & 50 & - & + & Maruyama et al. $1987 b$ \\
\hline \multirow[t]{14}{*}{$\beta$-casein } & $f(57-64)$ & SLVLPVPE & 39 & + & - & Yamamoto et al. 1994 \\
\hline & $f(60-66)$ & YPFPGPIP & 500 & - & + & Meisel \& Schlimme, 1994 \\
\hline & $f(74-76)$ & IPP & 5 & + & - & Nakamura et al. 1995 \\
\hline & $f(84-86)$ & VPP & 9 & + & - & Nakamura et al. 1995 \\
\hline & $f(108-113)$ & EMPFPK & $423^{\ddagger}$ & + & - & Pihlanto-Leppälä et al. 1998 \\
\hline & $f(169-174)$ & KVLPVP & 5 & - & + & Maeno et al. 1996 \\
\hline & $f(169-175)$ & KVLPVPQ & 1000 & + & - & Maeno et al. 1996 \\
\hline & $f(177-179)$ & AVP & 340 & - & + & Maruyama et al. 1987a \\
\hline & $f(177-181)$ & AVPYP & 80 & - & + & Maruyama et al. 1987a \\
\hline & $f(177-183)$ & AVPYPQR & 15 & + & - & Maruyama et al. $1987 a$ \\
\hline & $f(179-181)$ & PYP & 220 & - & + & Maruyama et al. 1987a \\
\hline & $f(181-183)$ & PQR & $>400$ & + & - & Maruyama et al. 1987a \\
\hline & $f(193-198)$ & YQQPVL & 280 & + & - & Pihlanto-Leppälä et al. 1998 \\
\hline & $f(193-202)$ & YQQPVLGPVR & 300 & - & + & Meisel \& Schlimme, 1994 \\
\hline \multirow[t]{4}{*}{ к-casein } & $f(25-34)$ & YIPIQYVLSR & nd & - & + & Chiba \& Yoshikawa, 1991 \\
\hline & $f(35-41)$ & YPSYGLNY & nd & - & + & Chiba \& Yoshikawa, 1991 \\
\hline & $f(58-59)^{\S}$ & YP & 720 & + & + & Yamamoto et al. 1999 \\
\hline & $f(108-110)$ & IPP & 5 & + & - & Nakamura et al. 1995 \\
\hline
\end{tabular}

nd, not determined.

* Details of other casein-derived peptides/or related peptides which inhibit ACE are available within the references used to generate this Table.

† Peptide concentration required to inhibit ACE by $50 \%$.

$\ddagger \mathrm{IC}_{50}$ value given in $\mu \mathrm{g} / \mathrm{ml}$.

$\S$ This sequence also occurs in $\alpha_{S 1}$-casein $f(146-147)$ and $f(159-160)$ and in $\beta$-casein $f(114-115)$

mechanism of action of ACE and the conformational behaviour of ACE inhibitory peptides should lead to a better understanding of the antihypertensive potential of milk protein-derived peptides.

\section{Physiological effects}

ACE is widely distributed in mammalian tissues. It is present in plasma, lung, kidney, heart, skeletal muscle,

Table 2. Whey protein-derived angiotensin-I-converting enzyme (ACE) inhibitory peptides

\begin{tabular}{|c|c|c|c|c|c|c|}
\hline \multicolumn{2}{|c|}{ Peptide fragment/analogue } & \multirow{2}{*}{$\begin{array}{c}\text { Primary structure } \\
\text { (one letter code) }\end{array}$} & \multirow{2}{*}{$\begin{array}{c}\begin{array}{c}\mathrm{IC}_{50}{ }^{*} \\
(\mu \mathrm{mol} / \mathrm{l})\end{array} \\
1523\end{array}$} & \multirow{2}{*}{$\begin{array}{c}\text { Enzymatic } \\
\text { hydrolysis }\end{array}$} & \multirow{2}{*}{$\begin{array}{c}\text { Peptide } \\
\text { synthesis } \\
+\end{array}$} & \multirow{2}{*}{$\begin{array}{r}\text { Reference } \\
\text { Mullally et al. } 1996\end{array}$} \\
\hline$\alpha$-lactalbumin & $f(50-51)$ & & & & & \\
\hline & $f(50-53)$ & YGLF & 733 & + & + & Mullally et al. 1996 \\
\hline & $f(52-53)$ & LF & 349 & - & + & Mullally et al. 1996 \\
\hline & $f(105-110)$ & LAHKAL & 621 & + & - & Pihlanto-Leppälä et al. 1998 \\
\hline \multirow[t]{10}{*}{$\beta$-lactoglobulin } & $f(9-14)$ & GLDIQK & 580 & + & - & Pihlanto-Leppälä et al. 1998 \\
\hline & $f(15-20)$ & VAGTWY & 1682 & + & - & Pihlanto-Leppälä et al. 1998 \\
\hline & $f(102-103)$ & YL & 122 & - & + & Mullally et al. 1996 \\
\hline & $f(102-105)$ & YLLF & 172 & + & + & Mullally et al. 1996 \\
\hline & $f(104-105)$ & LF & 349 & - & + & Mullally et al. 1996 \\
\hline & $f(142-148)$ & ALPMHIR & 43 & + & + & Mullally et al. $1997 b$ \\
\hline & $f(146-148)$ & HIR & 953 & - & + & Mullally et al. $1997 b$ \\
\hline & $f(146-149)$ & HIRL & 1153 & - & + & Mullally et al. 1996 \\
\hline & $f(147-148)$ & IR & 695 & - & + & Mullally et al. 1996 \\
\hline & $f(148-149)$ & $\mathrm{RL}$ & 2439 & - & + & Mullally et al. 1996 \\
\hline Bovine serum albumin & $f(208-216)$ & ALKAWSVAR & 3 & - & + & Chiba \& Yoshikawa, 1991 \\
\hline
\end{tabular}

\footnotetext{
* Peptide concentration required to inhibit ACE by $50 \%$.
} 
pancreas, spleen, placenta, arteries, testes, uterus and brain. It is also present as a brush border membrane-bound enzyme on epithelial cells of human jejunum (Ondetti \& Cushman, 1982; Steve et al. 1988).

A number of studies in spontaneously hypertensive rats (SHR) have demonstrated an antihypertensive effect following intraveneous and oral ingestion of casein-derived ACE inhibitory peptides. These peptides correspond to tryptic (Maruyama et al. 1987b) and Lactobacillus helveticus protease (Yamamoto et al. 1994, 1999) digests of $\alpha_{\mathrm{s} 1^{-}}, \beta$ - and $\kappa$-casein. Oral ingestion of a tryptic digest of whole casein gave an antihypertensive effect in SHR (Karaki et al. 1990). A study in normotensive and mildly hypertensive human volunteers reported that twice daily ingestion of $10 \mathrm{~g}$ of a tryptic digest of casein for 4 weeks had an antihypertensive effect (Sekiya et al. 1992). A placebo-controlled study in hypertensive humans definitively demonstrated a significant reduction in blood pressure following daily ingestion of $95 \mathrm{ml}$ of Calpis sour milk (Hata et al. 1996). Milk fermented with Calpis sour milk starter (L. helveticus and Saccharomyces cerevisiae) contains highly potent tripeptide inhibitors of ACE, i.e. Val-Pro-Pro $(\beta$-casein $\mathrm{f}(84-86))$ and Ile-Pro-Pro $(\beta$-casein $\mathrm{f}(74-76)$ ) and $\kappa$-casein $\mathrm{f}(108-110)$ ), (Nakamura et al. 1995). It is worth noting that the ingested dose of these ACE inhibitory peptides was in the range of only 1.2 $1.6 \mathrm{mg}$.

ACE inhibitory peptides can be produced during the manufacture of a range of dairy products. Meisel et al. (1997) demonstrated that secondary proteolysis during cheese ripening leads to the production of ACE inhibitory peptides. The ACE inhibitory activity in cheese was mainly associated with the low-molecular-weight peptide fraction. It was also demonstrated that low levels of proteolysis, in for example, fresh cheese, quarg, yoghurt and protein hydrolysate supplemented sports nutrition products, were associated with low ACE inhibitory index values (Meisel et al. 1997). Rokka et al. (1997) demonstrated the presence of ACE inhibitory peptides (i.e. $\beta$-casein $\mathrm{f}(177-183)$ and $\mathrm{f}(193-202))$ in UHT milk prefermented with Lactobacillus casei ssp. rhamnosus and subsequently digested with pepsin and trypsin. Recently, Mullally et al. (1997a) showed that endoproteinase (trypsin, chymotrypsin, elastase and pepsin) digests of whey protein concentrate and fractions enriched in $\alpha$-lactalbumin and $\beta$-lactoglobulin could inhibit ACE in vitro. Furthermore, a tryptic fragment of $\beta$-lactoglobulin (Ala-Leu-Pro-Met-His-Ile-Arg, f(142148)) was identified having an $\mathrm{ACE} \mathrm{IC}_{50}=42.6 \mu \mathrm{mol} / 1$ (Mullally et al. 1997b). Pihlanto-Leppälä et al. (1998) identified several casein ( $\alpha_{\mathrm{s} 1^{-}}$and $\beta$-casein) and whey $(\alpha-$ lactalbumin and $\beta$-lactoglobulin) derived ACE inhibitory peptides following digestion of cheese whey and isoelectric casein with pepsin and trypsin. No animal or human studies are as yet available on the antihypertensive potential of whey protein-derived hydrolysates/peptides. However, it has been reported that food-derived ACE inhibitory peptides with $\mathrm{IC}_{50}$ values in the range $100-500 \mu \mathrm{mol} / \mathrm{l}$ can be of nutritive/physiological importance in that they could be active following oral administration (Sekiya et al. 1992). The majority of the peptides listed in Tables 1 and 2 have ACE inhibitory potencies within this range. It is noteworthy that Yamamoto et al. (1999) demonstrated that Tyr-Pro, having an ACE $\mathrm{IC}_{50}$ value of $720 \mu \mathrm{mol} / \mathrm{l}$, could mediate a significant hypotensive effect in SHR. Tyr-Pro, which can arise from $\alpha_{\mathrm{s} 1}$-casein $\mathrm{f}(146-147)$ and $\mathrm{f}(159-$ $160)$, $\beta$-casein $\mathrm{f}(114-115)$ and $\kappa$-casein $\mathrm{f}(58-59)$, was found in skim milk fermented with Lactobacillus helveticus CPN4. The Tyr-Pro dipeptide may result from the hydrolytic action of starter derived post-proline dipeptidyl aminopeptidase (PPDA) activity on casein peptides. PPDA releases amino acyl proline moieties from the N-terminus of peptides (Bouchier et al. 1999).

The antihypertensive potential of milk protein-derived peptides is dependent on the ability of these peptides to reach their target site without being degraded and as a consequence inactivated by the action of intestinal or plasma peptidases. Inhibition of ACE in lung, vascular, kidney and brain tissue by captopril, a drug commonly used in the control of blood pressure, is thought to be central to the antihypertensive effect (Velletri \& Bean, 1982; Unger et al. 1985). Resistance to peptidase degradation may be a prerequisite for an antihypertensive effect during the oral ingestion and the intravenous infusion of ACE inhibitory hydrolysates/peptides. For example, $\alpha_{\mathrm{s} 1}$-casein $\mathrm{f}(23-27)$, a potent ACE inhibitor in vitro, was shown to have no hypotensive effect in vivo (Maruyama et al. 1987b). A similar situation has been shown by Maeno et al. (1996) in the case of $\alpha_{\mathrm{s} 1}$-casein $\mathrm{f}(104-109)$. The presence of ValPro-Pro and Ile-Pro-Pro in heat-treated solubilised aortal fractions of SHR fed on Calpis sour milk demonstrates the resistance of these peptides to intestinal and circulatory peptidases in addition to the absorption of these peptides from the intestine (Masuda et al. 1996). Proline-containing peptides are generally resistant to degradation by digestive enzymes (Kim et al. 1972; Adibi \& Kim, 1981). Furthermore, tripeptides containing C-terminal Pro-Pro are reported to be resistant to proline specific peptidases (Yoshimoto et al. 1978; Mock et al. 1990). It is interesting that the tryptic peptide, $\beta$-lactoglobulin $\mathrm{f}(142-148)$, was resistant to further degradation by pepsin and chymotrypsin (Mullally et al. 1997b). On the other hand, peptide degradation or fragmentation may result in more potent ACE inhibitory activities. For example, removal of Cterminal glutamine from $\beta$-casein $\mathrm{f}(169-175)$ increased the in vitro ACE inhibitory potency from 1000 to $5 \mu \mathrm{mol} / \mathrm{l}$, however, both $\beta$-casein $\mathrm{f}(169-174)$ and $\mathrm{f}(169-175)$ had strong antihypertensive activities in SHRs (Maeno et al. 1996). These results emphasise the necessity of performing in vivo studies in all cases.

Several casein and whey protein-derived ACE inhibitory peptides having other biological activities have been reported. Albutensin A, bovine serum albumin $\mathrm{f}(208-$ 216), displays ileum contracting and relaxing activities in addition to ACE inhibitory activity (Chiba \& Yoshikawa, 1991). The casein-derived opioid peptide, $\beta$-casomorphin 7 also inhibits ACE (Meisel \& Schlimme, 1994). Recently, it was demonstrated that $\beta$-lactorphin, the whey proteinderived opioid peptide could inhibit ACE (Mullally et al. 1996). This multifunctional bioactivity nature of milk protein peptides merits further research in terms of the general nutritive/physiological consequences of milk protein ingestion. 
The majority of milk protein-derived peptides reported to date do not have ACE inhibitory potencies (Tables 1 and 2) approaching that of captopril $\left(\mathrm{IC}_{50}=0.006 \mu \mathrm{mol} / 1\right)$. However, being naturally derived these peptides would be expected not to have the side-effects associated with synthetically produced drugs used in the control of hypertension, i.e. cough and alterations in serum lipid metabolism (Ames, 1983; Seseko \& Kaneko, 1985; Nakamura, 1987).

\section{Conclusion}

Casokinins and lactokinins represent a group of bioactive peptides that have significant potential as naturally-derived agents for the prevention/control of blood pressure and related diseases. The widespread use of these peptides in functional foods/nutraceuticals requires ongoing studies, including extended clinical trials, to demonstrate their longterm efficacy and safety.

\section{References}

Adibi SA \& Kim YS (1981) Peptide absorption and hydrolysis. In Physiology of the Gastrointestinal Tract, pp. 1097-1122 [LR Johnson, editor]. New York: Raven Press.

Ames RP (1983) Negative effects of diuretic drugs on metabolic risk factors for coronary heart disease. American Journal of Cardiology 51, 632-638.

Ariyoshi Y (1993) Angiotensin-converting enzyme inhibitors derived from food proteins. Trends in Food Science and Technology 4, 139-144.

Bouchier PJ, FitzGerald RJ \& O'Cuinn G (1999) Hydrolysis of $\alpha_{S 1^{-}}$and $\beta$-casein-derived peptides with a broad specificity aminopeptidase and proline specific aminopeptidases from Latococcus lactis subsp cremoris AM2. FEBS Letters 445, 321-324.

Cheung H-S, Feng-Lai W, Ondetti MA, Sabo EF \& Cushman DW (1980) Binding of peptide substrates and inhibitors of angiotensin-converting-enyzme. Journal of Biological Chemistry 255, 401-407.

Chiba H \& Yoshikawa M (1991) Bioactive peptides derived from food proteins. Kagaku to Seibutsu 29, 454-458.

Erdos EG (1975) Angiotensin-I-converting enzyme. Circulation Research 36, 247-255.

FitzGerald RJ \& Meisel H (1999) Lactokinins: whey proteinderived ACE inhibitory peptides. Nahrung 43, 165-167.

Hata Y, Yamamoto M, Ohni M, Nakajima K, Nakamura Y \& Takano T (1996) A placebo-controlled study of the effect of sour milk on blood pressure in hypertensive subjects. American Journal of Clinical Nutrition 64, 767-771.

Karaki H, Doi K, Sugano S, Uchiya H, Sugai R, Murakami U \& Takemoto S (1990) Antihypertensive effect of tryptic hydrolysate of milk casein in spontaneously hypertensive rats. Comparative Biochemistry and Physiology 96C, 367-371.

Kim YS, Bertwhistle W \& Kim YW (1972) Peptide hydrolyses in the brush border and soluble fractions of small intestinal mucosa of rat and man. Journal of Clinical Investigation 51, 1419-1430.

Maeno M, Yamamoto N \& Takano T (1996) Identification of antihypertensive peptides from casein hydrolysate produced by a proteinase from Lactobacillus helveticus CP790. Journal of Dairy Science 73, 1316-1321.

Maruyama S, Mitachi H, Tanaka H, Tomizuka N \& Suzuki H (1987a) Studies on the active site and antihypertensive activity of angiotensin I-converting enzyme inhibitors derived from casein. Agricultural Biological Chemistry 51, 1581-1586.

Maruyama S, Mitachi H, Awaya J, Kurono M, Tomizika N \& Suzuki H (1987b) Angiotensin I converting enzyme inhibitory activity of the C-terminal hexapeptide of $\alpha_{\mathrm{s} 1}$-casein. Agricultural Biological Chemistry 51, 2557-2561.

Maruyama S, Nakagomi K, Tomizuka N \& Suzuki H (1985) Angiotensin I-converting enzyme inhibitor derived from an enzymatic hydrolysate of casein. II Isolation and bradykininpotentiating activity on the uterus and the ileum of rats. Agricultural Biological Chemistry 49, 1405-1409.

Maruyama S \& Suzuki H (1982) A peptide inhibitor of angiotensin I converting enzyme in the tryptic hydrolysate of casein. Agricultural Biological Chemistry 46, 1393-1394.

Masuda O, Nakamura Y \& Takano T (1996) Antihypertensive peptides are present in aorta after oral administration of sour milk containing these peptides to spontaneously hypertensive rats. Journal of Nutrition 126, 3063-3068.

Meisel H (1993) Casokinins as inhibitors of angiotensin-Iconverting enzyme. In New Perspectives in Infant Nutrition, pp. 153-159 [G Sawatski and B Renner, editors]. Stuttgart, New York: Thieme.

Meisel H, Goepfert A \& Guenther S (1997) ACE-inhibitory activities in milk products. Milchwissenschaft 52, 307-311.

Meisel H \& Schlimme E (1994) Inhibitors of angiotensinconverting-enzyme derived from bovine casein (casokinins). In $\beta$-Casomorphins and Related Peptides: Recent Developments, pp. 27-33 [V Brantl and $\mathrm{H}$ Teschemacher, editors]. Weinheim: VCH.

Mock WL, Green PC \& Boyer KD (1990) Specificity and pH dependence for acylproline cleavage by prolidase. Journal of Biological Chemistry 265, 19600-19605.

Mullally MM, Meisel H \& FitzGerald RJ (1996) Synthetic peptides corresponding to $\alpha$-lactalbumin and $\beta$-lactoglobulin sequences with angiotensin-I-converting enzyme inhibitory activity. Biological Chemistry Hoppe-Seyler 377, 259-260.

Mullally MM, Meisel H \& FitzGerald RJ (1997a) Angiotensin-Iconverting enzyme inhibitory activities of gastric and pancreatic proteinase digests of whey proteins. International Dairy Journal 7, 299-303.

Mullally MM, Meisel H \& FitzGerald RJ (1997b) Identification of a novel angiotensin-I-converting enzyme inhibitory peptide corresponding to a tryptic digest of bovine $\beta$-lactoglobulin. FEBS Letters 402, 99-101.

Nakamura H (1987) Effects of antihypertensive drugs on plasma lipid. American Journal of Cardiology 60, 24E-28E.

Nakamura Y, Yamamoto N, Sakai K, Okubo A, Yamazaki S \& Takano T (1995) Purification and characterization of angiotensin I-converting enzyme inhibitors from a sour milk. Journal of Dairy Science 78, 777-783.

Ondetti MA \& Cushman DW (1982) Enzymes of the reninangiotensin system and their inhibitors. Annual Review of Biochemistry 51, 283-308.

Ondetti MA, Rubin B \& Cushman DW (1977) Design of specific inhibitors of angiotensin-converting enzyme: new class of orally active antihypertensive agents. Science 196, 441-444.

Philanto-Leppälä A, Rokka T \& Korhonen H (1998) Angiotensin I converting enzyme inhibitory peptides derived from bovine milk proteins. International Dairy Journal 8, 325-331.

Rokka T, Syväoja E-L, Tuominen J \& Korhonen H (1997) Release of bioactive peptides by enzymatic proteolysis of Lactobacillus GG fermented UHT milk. Milchwissenschalt 52, 675-678.

Sekiya S, Kobayashi Y, Kita E, Imamura Y \& Toyama S (1992) Antihypertensive effects of tryptic hydrolysate of casein on normotensive and hypertensive volunteers. Journal of the Japanese Society of Nutrition and Food Science 45, 513517(in Japanese). 
Seseko S \& Kaneko Y (1985) Cough associated with the use of captopril. Archives of Internal Medicine 145, 1524.

Skeegs LT, Kahn JE \& Shumway NP (1956) The preparation and function of the angiotensin-converting enzyme. Journal of Experimental Medicine 103, 295-299.

Steve BR, Fernandez A, Kneer C, Cerda JJ, Phillips MI \& Woodward ER (1988) Human intestinal brush border angiotensin-converting enzyme activity and its inhibition by antihypertensive ramipril. Gastroenterology 94, 942-994.

Takano T (1998) Milk derived peptides and hypertension reduction. International Dairy Journal 8, 375-381.

Unger T, Ganten D, Lang RE \& Scholkens BA (1985) Persistent tissue converting enzyme inhibition following chronic treatment with Hoe498 and MK421 in spontaneously hypertensive rats. Journal of Cardiovascular Pharmacology 7, 36-41.

Velletri P \& Bean BL (1982) The effect of Captopril on rat aortic angiotensin-converting enzyme. Journal of Cardiovascular Pharmacology 4, 315-325.

Yamamoto N, Akino A \& Takano T (1994) Antihypertensive effects of peptides derived from casein by an extracellular proteinase from Lactobacillus helveticus CP790. Journal of Dairy Science 77, 917-922.

Yamamoto N, Maeno M \& Takano T (1999) Purification and characterisation of an antihypertensive peptide from yoghurtlike product fermented by Lactobacillus helveticus CPN4. Journal of Diary Science 82, 1388-1393.

Yoshimoto T, Fischl M, Orlowski RC \& Walter R (1978) Postproline cleaving enzyme and post-proline dipeptidyl aminopeptidase comparison of two peptidases with high specificity for proline residues. Journal of Biological Chemistry 253, 3708-3716. 